\title{
THE USE OF PROJECT BASED LEARNING METHOD IN DEVELOPING STUDENTS' CRITICAL THINKING
}

\author{
Iskandar \\ Postgraduate Studies, Universitas Kuningan, Indonesia \\ E-mail: iskandaruniku@gmail.com \\ Sri Mulyati \\ Postgraduate Studies, Universitas Kuningan, Indonesia \\ E-mail: sri.mulyati@gmail.com
}

\begin{abstract}
APA Citation: Iskandar, I., \& Mulyati, S. (2019). The use of project based learning method in developing students' critical thinking. Indonesian Journal of Learning and Instruction, 2(1), 71-78. doi: 10.25134/ijli.v2i01.1686.
\end{abstract}

\begin{abstract}
This research aims to determine the difference of students' critical thinking ability between class which get Project Based Learning (PjBL) method and expository method. The method use experimental method with factorial design $2 \times 2$. The research subjects are class X-IPS 1 as an experimental class consists of 32 students and class X-IPS 2 as a control class consists of 32 students. The data collection techniques use test and questionnaires. While, the data analysis technique uses two way Anova. From the result of data analysis, PjBL method is more effective in improving students' critical thinking ability compared with expository method. However, there is a difference in critical thinking skills, where students with high motivation levels are more effective than students with low motivation. For students who have high motivation but use PjBL method, it is better when compared with students who have high motivation but use expository methods in the control class. There is an interaction between learning methods with learning motivation in affecting the students' critical thinking ability. Therefore, it is recommended for teacher to use PjBL method on cooperative material. In PjBL method, teachers play an important role in the implementation of the learning process for it requires mastery of materials and good class management and students should actively participate in project execution activities to make learning more meaningful.
\end{abstract}

Keywords: critical thinking ability; expository method; learning motivation; Project Based Learning (PjBL) method.

\section{INTRODUCTION}

Entrepreneurship learning aims to develop students' entrepreneurship intention. This entrepreneurship intention will appear if the students understand deeply the meaning of the material being delivered. Therefore, the abilities of critical thinking and creative thinking are two main cases that should be developed in entrepreneurship learning. Yet to develop these two kinds of ability needs a learning process that requires students' involvement optimally. This is the main challenge encountered by the entrepreneurship teachers right now.
Unfortunately, the observation we conduct at the field shows that now teachers still orients to the completeness of material using simple method such as expository. As a result, students tend to receive more information and less afford the opportunities to develop their critical thinking ability. As stated by Ausubel (Bell, 1981), if this expository method is not packed creatively then it will result in the learning that concentrates more on the learning material only.

The fact can be seen from several drawbacks of learning process occurring at school now. Those drawbacks are: 1) 
students pay less attention to the teacher's explanation in each learning process, 2) students have less desire and spirit in studying, 3) students' low concentration during the learning process, and 4) students' low motivation in following the learning process. Based on the observation result, it was seen that students were still in doubt to ask and answer the teacher's question, and there were still many students who answered the question by only repeating the words on the question without any more critical and creative answers.

Therefore, to change students to think critically needs an innovation in case of the learning method used by the teacher so it can improve the students' learning outcomes. One of the creative method is Project Based Learning (PjBL) method. The PjBL method refers to the theory of social constructivism learning from Vygotsky that is believed to develop the students' critical thinking ability through the activity of problem solving contextually which is conducted by students cooperatively and project making which is done by students evidently. Yet in fact, it is not only the method that affects the learning outcomes, some studies show that the characteristics of each students, such as learning motivation level, also determines the students' learning outcomes. This phenomenon drives us to conduct a research on the correlation between learning method used and the high and low of the learning motivation level in affecting students' critical thinking ability.

Coming the rationale above, the problems of this research can be formulated as follows: 1) Is there any difference of students' critical thinking ability between the class using Project Based Learning (PjBL) method and the class using expository method? 2) Is there any difference of students' critical thinking ability between students with high learning motivation and low learning motivation? 3) For students with high learning motivation, is there any difference of critical thinking ability between the students in class using PjBL method and the students in class using expository method? 4) For students with low learning motivation, is there any difference of critical thinking ability between the students in class using PjBL method and the students in class using expository method? and 5) Is there any interaction between learning method and learning motivation in affecting the students' critical thinking ability?

Norris and Ennis in Alec Fisher (2009, p.4) state critical thinking as "rational and reflective thinking that focuses on decision making about what is done or believed." Furthermore, they explain that rational means that the thinking is based in the facts to produce the best decision, and reflective means finding the best solution consciously and explicitly. From Norris and Ennis' definition above, it can be concluded that critical thinking is thinking which is directed to purpose. The purpose of critical thinking is evaluating the best action or belief. Norris and Ennis focus the framework on the thinking process that involves the information collection and criteria implementation to consider a series of different action or opinion, with indicators: 1) elementary classification; 2) basic support; 3) inferring, 4) advanced clarification; and 5) strategies and tactics.

Kosasih (2014, p.96) explains that project based learning is "the learning method that uses project or activity as the purpose." Based on the definition above, it can be concluded that project based learning (PjBL) focuses on students' activity in form of information collection and its use to produce something beneficial for the students themselves or other people, but still related to the Basic Competence in Curriculum. PjBL is believed to improve students' academic achievement, as much observed by Rais (2010), Bell (2010), Fatmawati and Rustaman (2011), Lyesmaya (2011) and so on, in Rahman (2014, p.4) basically concludes that PjBL can improve the concept mastery, the problem solving ability, the communication ability, the critical thinking and creative thinking ability, and can grow characters. 
Winkel (2005, p.160) calls learning motivation the whole mental driving force inside the students' that causes the learning activity to achieve a purpose. According to Uno (2011, p.23), learning motivation is internal and external encouragement on students who are learning to hold behavior, generally with some supporting indicators or elements. Those indicators are: the desire and pretension to success, encouragement and needs in learning, future expectation and dreams, appreciation in learning and conducive learning environment.

The hypotheses in this research are as follows: 1) There is difference of students' critical thinking ability between the class with Project Based Learning (PjBL) method and the class with expository method; 2) There is difference students' critical thinking ability between those with high and low learning motivation; 3) For students with high learning motivation, there is difference of critical thinking ability between the students in class using PjBL method and the students in class using expository method; 4)
For students with low learning motivation, there is difference of critical thinking ability between the students in class using PjBL method and the students in class using expository method; and 5) There is an interaction between learning method and learning motivation in affecting the students' critical thinking ability.

\section{METHOD}

This research had been carried out to determine the difference of students' critical thinking ability between class which get Project Based Learning (PjBL) method and expository method. The research subjects are students in SMA Negeri 2 Kuningan on academic year 2016/2017. All the participant are the students in class X-IPS 1 as an experimental class consists of 32 students and class X-IPS 2 as a control class consists of 32 students.

The method used quasi experimental method with factorial design $2 \times 2$. The research design can be described as follows:

Table 1. Factorial design $2 \times 2$

\begin{tabular}{ccc}
\hline Students' Learning & \multicolumn{2}{c}{ Learning Method (A) } \\
\cline { 2 - 3 } Motivation Level $(\mathbf{B})$ & PjBL Method $\left(\mathrm{A}_{1}\right)$ & Expository Method $\left(\mathrm{A}_{2}\right)$ \\
High Level of Learning & $\left(\mathrm{A}_{1}, \mathrm{~B}_{1}\right)$ & $\left(\mathrm{A}_{2}, \mathrm{~B}_{1}\right)$ \\
Motivation $\left(\mathrm{B}_{1}\right)$ & $\left(\mathrm{A}_{1}, \mathrm{~B}_{2}\right)$ & $\left(\mathrm{A}_{2}, \mathrm{~B}_{2}\right)$ \\
$\begin{array}{c}\text { Low Level of Learning } \\
\text { Motivation }\left(\mathrm{B}_{2}\right)\end{array}$ & & \\
\hline
\end{tabular}

In this research, three types of instruments were employed for data collection. There were test, questionnaire, and documentation study. Beside that, data analysis technique in this research used two way Anova. In the test result of research instrument, there were four stages as follows: 1) Validity test was about 50 items of valid questions and 35 items of valid questionnaire statements; 2) Reliability test conducted the test instrument of critical thinking skill and reliable questionnaire since $>0.70 ; 3$ ) Question difficulty test was about 6\% difficult questions, 4\% easy questions and $90 \%$ medium questions; and 4) Distinguishing power test was about $8 \%$ items of good enough questions, $22 \%$ items of good questions and $70 \%$ items of very good questions.

\section{RESULTS AND DISCUSSION}

Overall, the output of statistical result with factorial design $2 \times 2$ which can be used to describe the hypothesis 1 to the hypothesis 5 can be presented more clearly by the researcher as follows: 
Table 2. Result of hypothesis test two way Anova

\begin{tabular}{cccccc}
\hline \multicolumn{7}{c}{$\begin{array}{c}\text { Tests of Between-Subjects Effects } \\
\text { Dependent Variable: KBK } \\
\text { Type III Sum of } \\
\text { Squares }\end{array}$} & df & Mean Square & F & Sig. \\
Source & $2740,365^{\mathrm{a}}$ & 3 & 913,455 & 8,228 &, 000 \\
Corrected Model & 367476,514 & 1 & 367476,514 & 3309,911 &, 000 \\
Intercept & 1278,718 & 1 & 1278,718 & 11,518 &, 001 \\
METODE & 1288,915 & 1 & 1288,915 & 11,609 &, 002 \\
MOTIVASI & 273,986 & 1 & 273,986 & 5,054 &, 017 \\
METODE $*$ & 6661,385 & 60 & 111,023 & & \\
MOTIVASI & 377244,000 & 64 & & \\
Error & 9401,750 & 63 & & \\
Total & a. R Squared $=, 419$ (Adjusted R Squared =,406) \\
Corrected Total & \multicolumn{7}{c}{} \\
\hline \multicolumn{7}{c}{}
\end{tabular}

\section{Hypothesis test 1}

Referring to the table above, through the Tests of Between-Subjects Effects on the method line obtained $\mathrm{F}_{\text {count }}$ of $11.518>$ compared with $\mathrm{F}_{\text {table }}(0.05 ; 1.64)=3.99$, then obtained its significance coefficient of 0.001 $<0.05$. Thus, the first null Hypothesis in this research is rejected, from the $\mathrm{F}$ test where $\mathrm{F}_{\text {count }}>\mathrm{F}_{\text {table }}$ it is also from the significance value which is less than $0.05(0.001<0.05)$ meaning significant. It shows that hypothesis that stated there is difference of students' critical thinking ability between the class using Project Based Learning (PjBL) method and the class using expository method can be accepted.

\section{Hypothesis test 2}

On the motivation line is obtained $F_{\text {count }}$ of $11.609>$ compared with $\mathrm{F}_{\text {table }}(0.05 ; 1,64)=3,99$ then obtained its significance coefficient of $0.002<0.05$. Thus, the second null Hypothesis in this research is rejected since besides proven from the $F$ test where $F_{\text {count }}>$ $\mathrm{F}_{\text {table }}$ it is also from the significance value which is less than $0.05(0.001<0.05)$ meaning significant. It shows that hypothesis that stated there is difference of students' critical thinking ability between those with high and low learning motivation can be accepted. From the mean value of both experimental and control class, for the students with high motivation shows higher mean value compared with the mean value of critical thinking ability of students with low level of motivation.

\section{Hypothesis test 3}

Referring to the table of result of hypothesis test through the Post-Hoc test is obtained its significance efficient (p-value) of 0.01 if compared with significance level $(95 \%=$ 0.05 ) then it is significant because $0.01<$ 0.05. Thus, the third null Hypothesis in this research is rejected, since proven from the post-hoc test it is obtained significant result $(0.01<0.05)$. It means that it shows the hypothesis that stated that for students with high learning motivation, there is difference of critical thinking ability between the students in class using PjBL method and the students in class using expository method can be accepted.

\section{Hypothesis test 4}

Referring to the table of result of hypothesis test through the Post-Hoc test is obtained its significance efficient (p-value) of 0.04 if compared with significance level $(95 \%=$ $0.05)$ then it is significant because $0.04<$ 0.05 . Thus, the fourth null Hypothesis in this research is rejected, since proven from the post-hoc test it is obtained significant result $(0.04<0.05)$. It means that it shows the hypothesis that stated that for students with low learning motivation, there is difference of critical thinking ability between the students in class using PjBL method and the students in class using expository method can be accepted. 


\section{Hypothesis test 5}

The result of hypothesis test through Tests of Between-Subjects Effects on the motivation method line obtained $\mathrm{F}_{\text {count }}$ of $5.054>\mathrm{F}_{\text {table }}$ $(0.05 ; 1.64)=3.99$, then obtained its significance coefficient of $0.017<0.05$. Thus, the fifth null Hypothesis in this research is rejected, since proven from the $\mathrm{F}$ test where $\mathrm{F}_{\text {count }}>$ $F_{\text {table }}$ it is also from the significance value which is lower than $0.05(0.017<0.05)$ which means significant. It shows that the hypothesis that stated that there is an interaction between learning method and learning motivation in affecting the students' critical thinking ability can be accepted. The magnitude of the effect between the two independent variables and the interaction can explain the variability of dependent variable that is 0.406 and the remains of 0.594 is affected by the other factors that are not observed in this research.

Based on the result of the research that has been conducted, it is obtained that there is significant difference between critical thinking ability of students using PjBL method and students using expository method. After finding out the difference, it got the fact that experimental class using PjBL method has more excellent critical thinking ability if compared with control class using expository learning method. While the results of this research are in line with other relevant researches such as the research conducted by Jamaludin (2013) with thesis entitled "The Effect of Project Based Learning (PjBL) on Critical Thinking, Creative Thinking, and Scientific Behavior in Senior High School Bandung". It results in the conclusion that project based learning can develop significantly the ability of critical thinking and creative thinking compared with conventional learning.

As stated by Sanjaya (2009, p.175), what is meant by expository method is the method used by teacher in teaching the overall concept. So, if we study more deeply, the core of expository method is the learning method that emphasizes more on the material delivery verbally from a teacher to the students with purpose that the students can master the lesson material optimally. Therefore, expository method which is a form of teacher centered approach is considered less able to facilitate the higher learning process where the main focus of this method is the students' academic skills only. agar peserta didik dapat menguasai materi pelajaran secara optimal. Coming from the theory proposed by Ausubel (Bell, 1981) which states that if this expository method is not creatively packed well by teacher, then the learning will concentrate more on any lesson material and less able to involve participation and interaction with students.

From the result of the research above, it describes that $\mathrm{PjBL}$ method can develop the high order thinking skill of students such as critical thinking, by using supporting constructivism learning, students can develop their own thinking ability. Where in this method, students creativity and activity can help them to stand alone in their cognitive life. They will be helped to be person who critically analyze something since they are thinking not only imitating. Remembering that each student has different learning style, then $\mathrm{PjBL}$ gives chance to the students to dig up the content (material) by using many ways meaningful for themselves, and conducting experiment collaboratively. $\mathrm{PjBL}$ method is an in-depth investment about a real world topic, this is will be valuable for the learning process done by the students.

It is seen when the discussion process happens with $\mathrm{PjBL}$ method, the students have been able to analyze arguments appearing from various thoughts proposed by each individual. In the question-answer process, the students are more enthusiastic to propose various questions as the form of curiosity inside themselves, while the students who have been able to answer various questions and problems existing by correlating between knowledge they have based in the experience they got during the completeness of project at the field. So, during the implementation of PjBL method, the students can argue by using logic and factual proofs.

From the average score of the students with high and low motivation level, it can be 
clearly seen that the average of critical thinking ability of students with high motivation level is higher than the students with low motivation level. Besides, in line with what is stated by McClelland (1953, p.104) which explicitly stated that someone who has high achievement motivation has better learning outcomes rather than those who have low motivation level. Essentially, it can be concluded that there is correlation or positive relationship between the level of students' learning motivation on their learning outcomes, which means that the stronger/higher the learning motivation, the better the learning outcomes. Therefore, the teachers' role to manage the learning motivation is crucial and can be done through various learning activities.

The result of hypothesis test shows that there was interaction between learning method and learning motivation significantly on the students' critical thinking ability. In this case, the teacher should do things that can encourage students in learning. Their teaching ability makes themselves as model that can arouse the curiosity and the ability inside the students is the main asset in arousing motivation. Essentially, it can be concluded that overall, the use of learning method affected the high and low of learning motivation and then could affect the students' critical thinking ability together.

\section{CONCLUSION}

Based on the result and data analysis above, it can be concluded that there is difference of students' critical thinking ability between class which uses Project Based Learning (PjBL) method and expository method. It is seen from the mean value of students' critical thinking ability for PjBL class is higher than the mean value of students' critical thinking ability for control class which used expository learning method. It means that the project based learning method (PjBL) is more effective in developing students' critical thinking ability rather than expository method.

There is difference of students' critical thinking ability between those with high and low learning motivation. Where it is seen from the mean value of students with high motivation level is higher than the mean value of critical thinking ability of students with low motivation level. It means that the critical thinking ability of students with high motivation level is more effective than the students with low motivation level.

For students with high learning motivation, there is difference of critical thinking ability between the students in class using PjBL method and the students in class using expository method. It is seen from the mean value of critical thinking ability of students with high motivation level in experimental class is higher than the students with high motivation level in control class. It means that students with high motivation level in experimental class by using $\mathrm{PjBL}$ method is better than the students with high motivation level but use expository method in control class.

For students with low learning motivation, there is difference of critical thinking ability between the students in class using PjBL method and the students in class using expository method. It is seen from the mean value of students with low motivation level in experimental class is higher than the students with low motivation level in control class. It means that students with low motivation level in experimental class by using PjBL method is better than the students with low motivation level but use expository method in control class.

There is an interaction between learning method and learning motivation in affecting the students' critical thinking ability. It means that the effect of methods on the critical thinking ability depends also in the students' learning motivation. It also means that learning method and students' motivation level are correlated each other in affecting the students' critical thinking ability.

Some suggestions can be given by the writer are as follows: 1) For all teachers, use and implement the project based learning (PjBL) method in the entrepreneurship learning process, since based on the result of 
the research, it shows that this project based learning (PjBL) method is more effective rather than the expository method that is often used by the teachers; 2) Based on the result of research, it stated that the element of students; learning motivation affects much on the quality rather than the learning. It is seen from the students with high motivation level got higher learning outcomes as compared with the students with low motivation level.

Therefore, the teacher should truly pay attention to the students as a motivator. Also, the teacher needs to grow students' learning motivation. To get optimal learning outcomes, the teacher is required to creatively arouse the students' learning motivation, so that it can form the students' effective learning behavior; 3) In implementing $\mathrm{PjBL}$ learning method, it is important to pay attention to the compatibility of learning material, the availability of media and infrastructure, and the time division thoroughly. This learning method is suitable with the learning material related to the content, type and objectives of the subject that require the students to be able to do analysis of the problems and the management of further information through more useful solutions; 4) In PjBL method, teachers play important role in the implementation of learning process, therefore, it needs creativity and good class management; 5) Teachers should involve the students' participation actively in the activity of project implementation, so the knowledge got by the students truly attached and the learning process can be more meaningful; and 6) In the process of $\mathrm{PjBL}$ learning, teachers should train the students to be accustomed to correlate concepts, data, and facts in the material they study which exist in the students' environment and analyze them well so in the end they can critically take a decision that is alternative solution.

\section{REFERENCES}

Bell, F. H. (1981). Teaching and learning mathematics (In secondary school). USA: Wm.C. Brown Company Publisher.

Filsaime, D. K. (2008). Menguak rahasia berpikir kritis dan kreatif. Jakarta: Prestasi Pustakaraya.

Fisher, A. (2009). Critical thinking an introduction. Jakarta: Erlangga.

Hamzah, B. U. (2006). Teori motivasi dan pengukurannya analisis di bidang pendidikan. Jakarta: Bumi Aksara.

Jamaludin, D. N. (2013). Pengaruh project based learning (pjbl) terhadap berpikir kritis, berpikir kreatif, dan sikap ilmiah. Bandung: UPI.

Kosasih, E. (2014). Strategi belajar dan pembelajaran implementasi kurikulum 2013. Bandung: Yrama Widya.

McClelland, D. C., Atkinson, Clark \& Lowell. (1953). The achievment motive. New York: Halsted Press.

Rahman, T. (2014). Makalah model pembelajaran project based learning. Bandung: Universitas Pendidikan Indonesia.

Sanjaya, W. (2009). Strategi pembelajaran berorientasi standar proses pendidikan. Jakarta: Kencana Prenada Media Group.

Winkel. W. S. (2005). Psikologi pengajaran. Jakarta: PT. Grasindo. 
Iskandar \& Sri Mulyati

The use of project based learning method in developing students' critical thinking 